\title{
ANALYSES OF BROILER CHICKEN'S MARKETING IN TRADITIONAL MARKET OF MEDAN CITY
}

\author{
Yusrizal Fachri, A Hakim Daulay, Nevy Diana Hanafi, M Tafsin, and E Mirwandhono \\ Animal Production Study Program, Faculty of Agriculture, University of Sumatera Utara \\ Medan 20155 \\ E-mail: yusrizal22fachri@gmail.com
}

\begin{abstract}
The purpose of this research is to identify the characteristics of marketing institutions, marketing chain, marketing function, and analyze added value in broiler marketing institutions in traditional market of Medan City from April until May 2017. This research used primary and secondary data that obtained from observation and interview of respondents and also the related agencies. The location of the research was determined purposively method and determination of respondents with accidental sampling method that has 99 respondents. The data analysis by descriptive analyses and added value analyses.

The results showed the characteristic of respondents were dominated by male sex $(72,75 \%)$ with an experience of 11-20 years $(56,19 \%)$ with 6-10 employees $(47,99 \%)$, aged $41-50$ years $(57,99 \%)$ and had senior high school education level / equal $(45,34 \%)$. There were five kinds of marketing chains where the biggest marketing chains that was marketing chains broiler farmers to collectors then to slaughterers at once retailers with life broiler chicken input then become carcass product to retailers and to consumers. The exchange function and the facility function are done by each marketing institution, processing on the physical function is not found in the collectors level. The highest added value was found in slaughterers at once

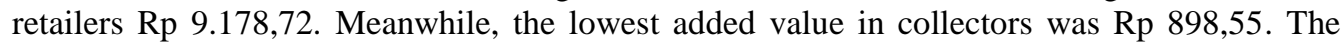
conclusion, the biggest marketing chain involved all the marketing institutions so the bigger the marketing margin that is formed the more profitable they are, but the higher the price the consumer pays. The shorter the marketing chain the more it gives a big profit to broiler farmers.

Key words: Marketing, Added Value, Broiler Chicken
\end{abstract}

\section{Introduction}

Medan city is the highest population density than other areas in north sumatra with a population of -2.122 .804 people with an average spending more than five hundred Rp per capita per month .This capital of north sumatra has the potential major market to market any product in which has 52 traditional markets BPS Medan city [1]. Traditional market is one of the places where the product marketing activity chicken ranch such as broiler chicken or commonly called.

Chicken meat consumption increased the highest than other meat producers. Some reasons are chicken relatively inexpensive than other meats, chicken better in terms of healthdue containing little fat and rich protein, no any religious banning him to consuming chicken meat,chickenhave a sense of accepted all groups and all of the community, chicken quite easily be turned into a product processing high value, easily stored, and easily consumed. Meat chicken obtained from other cities outside such 
as Deli Serdang district, Langkat district, Binjai city, Serdang Bedagai district and through GPPU (poultry farmer's business association).

Chicken marketing involved various marketing institutions.Marketing institutions are mutually marketing deals in doing activity marketing broiler chicken, so as to form a marketing chain. Marketing activity was conducted by the marketing of each institution in distributing broiler chicken from breeders until to the consumer end will create added value that profitable. Added value generated is one of the objectives of development strategy agricultural and agroindustry to the business of marketing broiler chicken done by each marketing institutions.

This causes broiler chicken has the potential to continuously developed, so it needed marketing activities good to meet consumption broiler chicken meat in the region of the city of medan. Researcher feels that should be did research on analyses of broiler chicken's marketing in traditional market of Medan city.

\section{Reasearch Methodology}

\subsection{Location and Timing}

This research was conducted in three traditional markets located within the city of Medan, the province of north sumatra.This research was held from April to May 2017.

\subsection{Research Methodology}

Research locations were selected purposively in some traditional markets in differentsubdistrict in the city of Medan.Traditional markets selected as the research locations is Pusat market in Medan Kota sub-district, Medan Deli market(Brayan) in west Medan sub-district, and Sei Kambing market in Medan Helvetia sub-district. The reasons to select third of traditional markets as research locations broadly based land and number of traders.A method of the determination of sample was done with the methods accidental (investigation), samples ofretailer traders used consist of 30 retailers in each market with 90 samples Walpole [2]. The samples of slaughterers and collectorstraders were done with the determination of where is under 30 samples so they have to be taken all with 9 samples Sugiyono [3].

\subsection{Data Collection Method}

The data was used in this research consisting of two sources, the primary and secondary data.The primary data was obtained through the observation in the field and interview with respondents. The interview with respondents based on the tools of the questionnaire made in accordance with problems and research's purposes. Secondary data was the written data obtained from searching for the literature study, data statistics of Medan city, and data of other institutions associated with the interests of research.

\subsection{Data Analysis}

Data analysis done include:

-Descriptive analysis to know the characteristics of marketing institution, marketing channels, and marketing functions.

-Value-added analysis that is seen as an effort to implement the principles of distribution and serves as one indicator of the success of an activity. The value added analysis method used is Hayami et al., [4].

\section{Results and Discussion}

\subsection{Characteristics of Marketing Institutions}

Characteristics of respondents observed in this study include the gender of the respondent, the age of the respondent, the level of education that has been taken by the respondent, the length of 
business that has been carried out by the respondent, and the labor involved in the respondent's business. Below in Table 2.

Table 2.Characteristics of Marketing Institutions

\begin{tabular}{|c|c|c|c|c|c|c|c|}
\hline \multirow[t]{2}{*}{ Gender } & \multicolumn{2}{|c|}{ Retailers } & \multicolumn{2}{|c|}{ Slaughterers retailer } & \multicolumn{2}{|c|}{ Collectors } & \multirow{2}{*}{$\frac{\text { Average }}{\%}$} \\
\hline & People & $\%$ & People & $\%$ & People & $\%$ & \\
\hline Male & 55 & 61,11 & 4 & 57,14 & 2 & 100 & 72,75 \\
\hline Female & 35 & 38,89 & 3 & 42,86 & 0 & 0 & 27,25 \\
\hline Total & 90 & 100 & 7 & 100 & 2 & 100 & 100 \\
\hline \multirow[t]{2}{*}{ Age } & \multicolumn{2}{|c|}{ Retailers } & \multicolumn{2}{|c|}{ Slaughterers retailer } & \multicolumn{2}{|c|}{ Collectors } & Average \\
\hline & People & $\%$ & People & $\%$ & People & $\%$ & $\%$ \\
\hline $20-30$ & 8 & 8,89 & 1 & 14,28 & 0 & 0 & 7,72 \\
\hline $31-40$ & 54 & 60 & 0 & 0 & 0 & 0 & 20 \\
\hline $41-50$ & 28 & 31,11 & 3 & 42,86 & 2 & 100 & 57,99 \\
\hline$\leq 55$ & 0 & 0 & 3 & 42,86 & 0 & 0 & 14,29 \\
\hline Total & 90 & 100 & 7 & 100 & 2 & 100 & 100 \\
\hline \multirow{2}{*}{ Education } & \multicolumn{2}{|c|}{ Retailers } & \multicolumn{2}{|c|}{ Slaughterers retailer } & \multicolumn{2}{|c|}{ Collectors } & Average \\
\hline & People & $\%$ & People & $\%$ & People & $\%$ & $\%$ \\
\hline PS & 15 & 6,67 & 1 & 14,29 & 0 & 0 & 10,32 \\
\hline JHS & 46 & 1,11 & 1 & 14,29 & 1 & 50 & 38,47 \\
\hline SHS & 26 & 8,89 & 4 & 57,13 & 1 & 50 & 45,34 \\
\hline College & 3 & $;, 33$ & 1 & 14,29 & 0 & 0 & 5,87 \\
\hline Total & 90 & 100 & 7 & 100 & 2 & 100 & 100 \\
\hline \multirow[t]{2}{*}{ Long Business } & \multicolumn{2}{|c|}{ Retailers } & \multicolumn{2}{|c|}{ Slaughterers retailer } & \multicolumn{2}{|c|}{ Collectors } & Average \\
\hline & People & $\%$ & People & $\%$ & People & $\%$ & $\%$ \\
\hline $1-10$ & 50 & 55,56 & 3 & 42,86 & 0 & 0 & 32,81 \\
\hline $11-20$ & 36 & 40 & 2 & 28,57 & 2 & 100 & 56,19 \\
\hline $21-30$ & 4 & 4,44 & 2 & 28,57 & 0 & 0 & 11,00 \\
\hline$>30$ & 0 & 0 & 0 & 0 & 0 & 0 & 0 \\
\hline Total & 90 & 100 & 7 & 100 & 2 & 100 & 100 \\
\hline \multirow[t]{2}{*}{ Employees } & \multicolumn{2}{|c|}{ Retailers } & \multicolumn{2}{|c|}{ Slaughterers retailer } & \multicolumn{2}{|c|}{ Collectors } & Average \\
\hline & People & $\%$ & People & $\%$ & People & $\%$ & $\%$ \\
\hline $1-5$ & 89 & 98,89 & 3 & 42,86 & 0 & 0 & 47,25 \\
\hline $6-10$ & 1 & 1,11 & 3 & 42,86 & 2 & 100 & 47,99 \\
\hline $11-15$ & 0 & 0 & 1 & 14,28 & 0 & 0 & 4,76 \\
\hline$>16$ & 0 & 0 & 0 & 0 & 0 & 0 & 0 \\
\hline Total & 90 & 100 & 7 & 100 & 2 & 100 & 100 \\
\hline
\end{tabular}

Source: Primary Data Analysis 2017

From the table above it can be seen that the characteristics of marketing institutions dominated by male sex $(72.75 \%)$ while women $(27.25 \%)$, age $41-50$ years $(57.99 \%)$ while the age of $20-30$ years only $(7.72 \%)$, senior high school $(45.34 \%)$ while only $5.87 \%, 11-20$ years old $(56.19 \%)$ and $>30$ years none, 6-10 people $(47.99 \%)$ whereas> 16 persons did not exist.

\subsection{Marketing Functions}

The marketing functions of broiler in the traditional market of Medan City consist of exchange function, physical function, and facility function which can be seen in Table 3 .

From the above table it can be seen that every marketing institution plays a different marketing function. The functions of exchange (sale and purchase) as well as the function of facilities (standardization, market information, funding, and risk insurers) are carried out by all marketing institutions. While transportation is not carried out by retailers, the processing is not carried out by collectors, not always done by each marketing institutions. 
Table 3.MarketingFunctions

\begin{tabular}{llccc}
\hline No & $\begin{array}{l}\text { MarketingFunction } \\
\text { s }\end{array}$ & $\begin{array}{l}\text { Collector } \\
\text { s }\end{array}$ & $\begin{array}{l}\text { Slaughterer } \\
\text { s retailer }\end{array}$ & $\begin{array}{l}\text { Retailer } \\
\text { s }\end{array}$ \\
\hline 1 & Sales & $\sqrt{ }$ & $\sqrt{ }$ & $\sqrt{ }$ \\
\hline 2 & Purchase & $\sqrt{ }$ & $\sqrt{ }$ & X \\
\hline 3 & Transportations & 0 & 0 & 0 \\
\hline 4 & Storage & $\mathrm{X}$ & $\sqrt{ }$ & $\sqrt{ }$ \\
\hline 5 & Processing & $\sqrt{ }$ & $\sqrt{ }$ & $\sqrt{ }$ \\
\hline 6 & Standardization & $\sqrt{ }$ & $\sqrt{ }$ \\
\hline \multicolumn{7}{l}{ Market } & $\sqrt{ }$ & $\sqrt{ }$ \\
\hline 8 & Information & Provision of Funds & $\sqrt{ }$ & $\sqrt{ }$ \\
\hline 9 & Risk Insurers & $\sqrt{ }$ & $\sqrt{ }$ \\
\hline Source: Primary Data Analysis 2017 & & \\
Description: $\sqrt{:}$ doing the function \\
X: no doing the function \\
0: do not always do depending on the circumstances
\end{tabular}

\subsection{Marketing Chains}

Broiler chickens are sold to consumers of the marketing institutions involved. This marketing institution involves collectors, slaughterers at once retailer, and retailers.Marketing chain of broiler in the market that exist in Medan City, there are 5 kinds following Figure1.

1. Broiler Farmers

2. Broiler Farmers

3. Broiler Farmers

4. Broiler Farmers

$\rightarrow$ Collectors

Collectors

$\rightarrow$ Slaughterers at once retailer

Consumers

$\rightarrow$ Collector

Slaughterers at once retailer

- Retailers

$\rightarrow$ Consumers

5. Broiler Farmers

$\rightarrow$ Slaughterers at once retailer

Consumers

- Consumers

- Retailers - Consumers

Information: $\rightarrow$ Live Chicken Products

- Carcass

Figure 1. Marketing Chains

Based on the above figure, it is known that the largest marketing chain is on the second chain where from the broiler farmers to the collectors and slaughterers at once retailer with live chicken products then retailers and consumers with carcass. The shortest marketing chain on the fourth channel where everything from broiler farmers to slaughterers at once retailer to consumers.

\subsection{Added Value Analysis}

The marketing activities of broiler chickens conducted by each marketing institution provide added value from the commodity. Added value analysis is done to know the added value of marketing from live broiler chicken to be carcass which can be seen in Table 4 .

Table4. Average Added ValueBroiler Chicken's Marketing to Each Marketing Institution

\begin{tabular}{llll}
\hline VariableAdded Value & \multicolumn{1}{c}{ Collectors } & $\begin{array}{c}\text { Slaughterers } \\
\text { retailer }\end{array}$ & Retailers \\
\hline Output, Input dan Price & 1.600 & 366 & 84 \\
1. Output (Tail/Day) & 1.600 & 366 & 84 \\
2. Raw materials (Tail/Day) & 7 & 7,82 & 1,24 \\
3. Employees (HKP/Day) & 1,00 & 1,00 & 1,00 \\
4. Convertion factors & 0,004375 & 0,02136 & 0,01476 \\
5. Employeescoefficient (HKP/Tail) & 16.750 & 26.142 & 26.833 \\
6. Price of output (Rp/Tail) & $21.785,71$ & $9.974,42$ & $42.428,22$ \\
7. Average wage of employees (Rp/HKP) & & & \\
\hline
\end{tabular}

Revenue and Profit (Rp/Tail ofraw materials) 
8. Price of raw materials(Rp/Tail)

9. Price of other inputs (Rp/Tail)

10. Output value (Rp/Tail)

11. a. Added value (Rp/Tail)

b. Added value ratio (\%)

12. a. Employee benefits(Rp/Tail)

b. Employee share (\%)

13. a. Profit (Rp/Tail)

b. Profit rate $(\%)$

Reply Service Owner of Factor Production

14. Margin (Rp/Tail)

a. Employee income (\%)

b. Other input contributions (\%)

c. Corporate profits (\%)

Source: Primary Data Analysis 2017

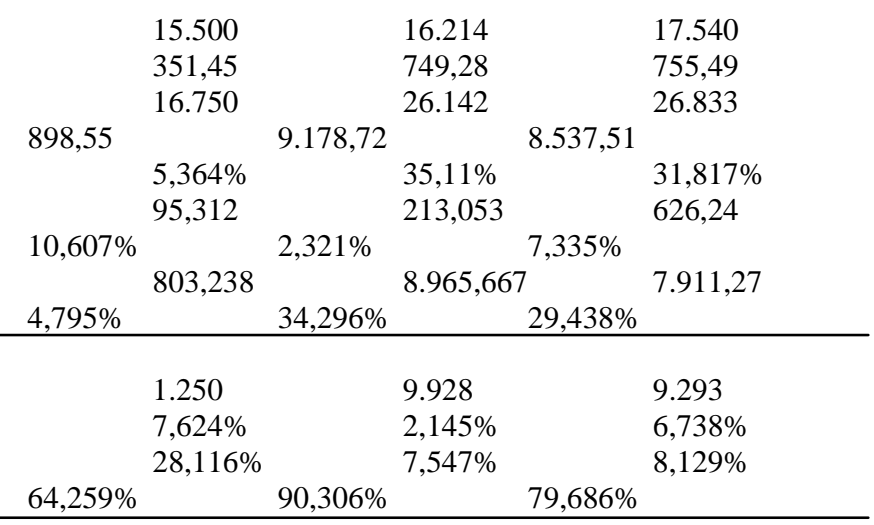

\subsection{Added Value Distribution}

The added value is the difference between the output value and the input price and other input contributions. The added value provides the greatest rewards in the employee of collectors at $\mathrm{Rp}$ 10,607 per head for every Rp 100.00 per broiler where the profit earned is Rp 803.238 per head or $89.39 \%$ of the added value. The distribution of added value can be seen inFigure2.

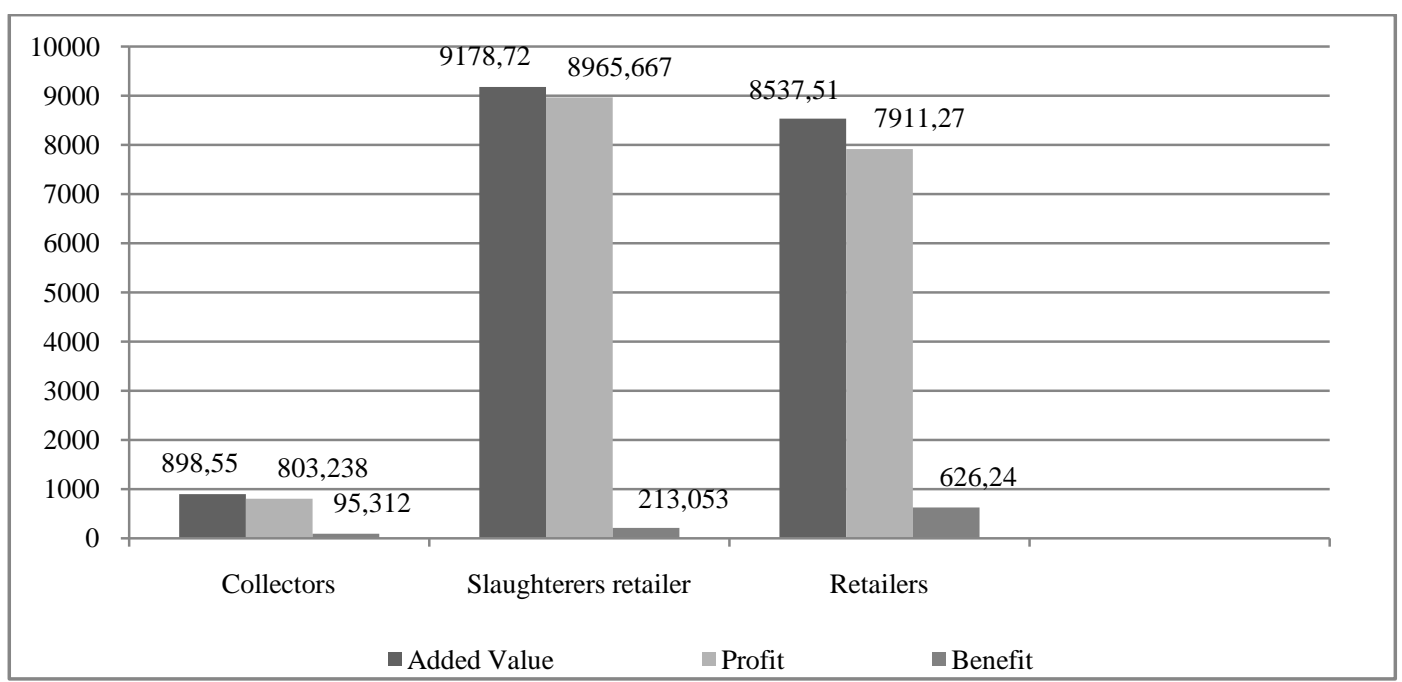

Figure2. Added Value Distribution Chart

\section{Conclussion and Suggestion}

\subsection{Conclusion}

The results showed the characteristic of respondents were dominated by male sex $(72,75 \%)$ with an experience of 11-20 years $(56,19 \%)$ with 6-10 employees $(47,99 \%)$, aged 41-50 years $(57,99 \%)$ and had senior high school education level / equal (45,34\%). There were five kinds of marketing chains where the biggest marketing chains that was marketing chains broiler farmers to collectors then to slaughterers at once retailers with life broiler input then become carcass to retailers andtoconsumers. The biggest marketing chain involved all the marketing institutions so the bigger the marketing margin that is formed the more profitable they are, but the higher the price the consumer pays. The shorter the marketing chain the more it gives a big profit to broiler farmers. The exchange function and the facility function are done by each marketing institution, processing on the physical function is not found in the collectors level. The highest added value was found in slaughterers at once retailers $\mathrm{Rp}$ 9.178,72. Meanwhile, the lowest added value in collectors was Rp 898,55. 


\subsection{Suggestion}

Marketing institutions are expected to continue to develop the marketing business of broiler chickens, because it has good prospects. This can be done by taking into account the marketing functions, as well as performing employee efficiency in order to reduce the benefits of employee so that it can gain more benefits

Broiler farmers should be expected to shorten marketing chains for more profits are formed The government is expected to make the regulations so that the selling price of live chickens go up, enlarge the portion of market share of broiler farmers as well as providing solutions to problems and confusion in national poultry.

\section{References :}

[1]. Badan Pusat Statistik Kota Medan. 2016. Kota Medan Dalam Angka 2016 (Medan City In Figures 2016). Badan Pusat Statistik Medan

[2]. Walpole, R E. 1992. PengantarStatistikaEdisi ke-3 (Introduction to 3rd Edition Statistics).PT. GramediaPustakaUtama. Jakarta

[3]. Sugiyono. 2009. MetodePenelitianKuantitatif, Kualitatifdan R\&D (Quantitative Research Methods, Qualitative and $R \& D$ ). Alfabeta. Bandung

[4]. Hayami, Y. T, Kawagoe. Y, Marooka and M. Siregar. 1987. Agricultural Marketing and Processing in Upland Java, a Perpective From Sunda Village. CEPRT. Bogor 